\title{
A Qualitative Analysis of the Agricultural Policy Dynamics and the Nigerian Economy : 1960-2015
}

\author{
Dr Patrick Ohunmah Igudia (PhD) \\ Department of Business Administration, \\ Ambrose Alli University, Ekpoma, Nigeria
}

Doi: 10.19044/esj.2017.v13n34p284 URL:http://dx.doi.org/10.19044/esj.2017.v13n34p284

\begin{abstract}
Historically, the agricultural sector constitutes one of the most important sectors of most countries including the highly industrialised ones like the USA, Japan, and England. In Nigeria, agriculture has been the engine of growth of its economy. However, this role has not been optimally exploited by successive administrations to develop strategic growth path for Nigeria as has been achieved by the aforementioned industrialised countries and some emerging ones like China and Brazil. Nigeria has a rich agricultural resource endowment and an avalanche of laudable agricultural policies that could turn her into an industrialised economy and reduce the incidence of poverty. The last in the series of laudable agricultural policies meant to entrench Nigeria's economic growth within the agricultural framework was the transformation agenda. The agricultural transformation agenda of the last administration (2011-2015) was intended to re-enact once again agriculture as the main driver of Nigeria's economic growth as in the 1960s and 1970s. Earlier attempts underperformed due principally to the ineffective implementation or complete abandonment of such policies. The result has been a fall in foreign exchange earnings, low GDP level and lack of sectoral linkages. This study made several recommendations including the need for a consistent increase in government budgetary allocation to the sector so as to redress this enigma and bring back the old post-independence glory of the sector.
\end{abstract}

Keywords : Agriculture, Agricultural Policies, Economic growth, Nigerian economy

\section{Introduction}

Historically, beginning with early men, agriculture has been found to be vital to human development. Apart from addressing some of the basic needs of man (such as providing food and being a source of income), 
agriculture also provides resources for the development of other sectors of the economy (Igudia, 2010). Indeed, industrial enterprises rely on agricultural outputs as raw materials. The food provided by agriculture satisfies the nutritional requirements of man. High nutrients increase birth and reduce death rates (increase in population) and by implication, effective demand for more food. Increased demand for more food increases greater economic activities that would lead to increase in employment which consequently lead to higher national income level. Thus, it can be asserted that the growth and development of any nation's economy depend on the articulate and progressive agricultural policy development and implementation (Akinboyo, 2008).

Up until the middle of the 1960s, agriculture was the engine of growth of the Nigerian economy (Aigbokhan, 1988) contributing over 60\% of the GDP. It was the leading sector in terms of occupational distribution and contribution to the GDP (Ogen, 2007) in the 1960s and early 1970s. The staple food crops in Nigeria include cassava, yams, corn, cocoyam, cowpeas, beans, sweet potatoes, millet, plantains, bananas, rice, sorghum, and a variety of fruits and vegetables. The leading cash crops used to be cocoa, citrus, cotton, groundnuts (peanuts), palm oil, palm kernel and rubber (NBS, 2014). Nigeria was the world's second largest producer of cocoa, the largest exporter of palm kernel and largest producer and exporter of palm oil. Nigeria was also a leading exporter of other major commodities such as cotton, groundnut, rubber and hides and skins (Alkali, 1997). Chief among the export destinations for Nigerian agricultural exports were Britain, the United States, Canada, France, and Germany. Even though this sector relied on peasant farmers using traditional tools and indigenous farming methods, the sector still blossomed, and the farmers produced about $70 \%$ of Nigeria's exports and 95\% of its food needs (Lawal, 2011, 1997; Nwokeoma, 2008). However, all that changed when oil production became largely commercial beginning from the mid-1960s. Although only a tiny proportion of the population benefited from the oil boom, investment in agriculture was deliberately allowed by various administrations to decline to the extent that its productivity as at the early 1990s lagged behind even some of the poorest countries in Sub-Saharan Africa.

So, the discovery of oil at Oloibiri in Bayelsa State in commercial quantities in 1959 led to the neglect and plummeting of all agricultural activities including its derivatives such as food production for the citizenry, foreign exchange earnings for the nation and contribution to the GDP. With the dwindling fortunes of agricultural outputs and its slide in importance in the economy, it was evident that Nigeria has mismanaged its agricultural potentials. She also failed to apply and map its rich agricultural endowment to her economic growth strategies as did her earlier contemporaries like 
China, Brazil, and Malaysia. In the 1970s, Nigeria exuded a better prosperity than China when her per-capita GDP was US\$233.82 and ranked $88^{\text {th }}$ in the world whereas China had a GDP per capita of US\$111.82 (Uma et al., 2013). Regrettably, China today has left Nigeria far behind as it is ranked very highly in the world and regarded as an emerging economy being part of the BRIC countries. The reasons for Nigeria's abysmal performance are numerous and multifarious. Uma et al. (2013) argued that part of the reasons there is sluggish economic growth in Nigeria is attributable to three things:

i. Policy summersault or inconsistent government policies on agriculture arising from the discountenancing of every policy initiatives of an old administration by a new one no matter how laudable,

ii. Geometric population growth, and

iii. Lack of interest in agriculture as a means of livelihood due mainly to its abandonment by the government which has consistently mobilised resources from agriculture to other sectors of the economy thereby discouraging those in the sector by using anti-agriculture policies.

Other reasons may also include corruption and lip-service paid to the implementation of laudable agricultural policies by successive administrations (Ogen, 2007). Nigeria does not lack sound and achievable agricultural policies. What it lacks is the will to implement such policies to the letter (Uma et al., 2013). The implication is the near-total neglect of the agricultural sector. By neglecting the sector for so long, there was naturally a backlash with adverse consequences on the growth of the economy considering the direct correlation between agriculture and economic growth (Rostow, 1960). That is the crux of the matter.

One of Nigeria's most challenging issues for a long time now has been her underperformance in three critical areas: poverty eradicate, attainment of food security, and global competition in agriculture (Akinyoade et al., 2013) within an enduring and sustainable environmental management (Manyong et al., 2003). Thus, Nigeria has failed to attain economic growth and development through a well articulated and coordinated commercialised agriculture (Olukunle, 2013). As a consequence, researchers (Uma et al., 2013; Ugwu and Kanu, 2012; Manyong et al., 2003) have suggested a paradigm shift from policies that only emphasise increase in agricultural produce/output to more target-specific, integrated and interlinked approaches. Such policy strategies should emphasise marketbased or agro-business that is rooted in private sector participation for the needed investment funds and competencies.

However, various research has produced conflicting positions regarding the actual impact of agriculture on Nigeria's overall economic direction. While majority suggest that agriculture has positively impacted markedly on economic growth in Nigeria through its impressive share of the 
nation's GDP, the supply of food to its citizenry, employment of the labour force, and supply of raw materials to the industry, others contend that the impact at best has been insignificant. By joining in the debate, this paper aims to achieve two things: first, to examine the agricultural development policies of the federal government covering various administrations from 1960 to 2014. It intends to signpost the various intentions and efforts made by each of the several administrations in their respective attempts to grow and develop the Nigerian economy through agriculture. Second, to determine whether agriculture has had any impact on the Nigerian economy based on the identified policies using two indices - the gross domestic product (GDP) and foreign private investment (FPI) statistics as growth indicators. On the one hand, GDP is used as a proxy for economic growth while on the other, FPI index is used as a measure of agricultural policy direction towards commercialising agriculture and value addition within the agricultural valuechain. A high FPI indicates positive policy initiatives towards commercialization and value addition in agriculture and therefore better private sector participation with the capacity to invest both capital and competencies.

The paper uses data obtained from secondary sources which include Statistical Bulletin for various issues and Annual Reports and Statement of Accounts for various years of the Central Bank of Nigeria (CBN), and the Annual Abstracts of Statistics for various years of the National Bureau of Statistics (NBS). Data included total expenditure figures, GDP figures, labour employment figures, foreign private investment figures, and export figures. Data analysis was descriptive using ratios, averages, percentages, and growth rates to demonstrate our arguments presented in tables. This paper, therefore, has been organised around five sections including this introduction. In Section 2 we present the conceptual and theoretical constructs and undertake an empirical review of the literature with particular reference to the historical evidence of some industrialised and emerging countries. The intention is to illustrate how these countries used agriculture and the associated activities to facilitate their economic developments. Section 3 briefly examines the agricultural policies and programmes in Nigeria from 1960 to 2014 and also identifies some of the gains of the Transformation Agenda of President Jonathan's administration. Section 4 descriptively analyses data using some growth indicators. Finally, section 5 is conclusion and recommendations.

\section{Theoretical Constructs and Literature Review The Concept of Agriculture}

In this study, agriculture has been conceptualised from the lenses of Umaru and Zubairu (2012), Rimando (2004), Rubenstein (2003), and 
Abellanosa and Pava (1987). Umaru and Zubairu (2012: p. 759) defined agriculture as "the cultivation of land, raising and rearing of animals for the purpose of production of food for man, feed for animals and raw materials for industries". In his study, Rimando (2004) opined that agriculture is the systematic raising of useful plants and livestock under the management of man (p.1). In a more elaborate and all-encompassing definition, Rubenstein (2003) sees agriculture as "the deliberate effort to modify a portion of the earth's surface through the cultivation of crops and the raising of livestock for sustenance or economic gain" (p. 496). The duo of Abellanosa and Pava (1987: p. 238) defined agriculture as "the growing of both plants and animals for human needs". From these definitions, the concept of agriculture does not only cover the production of food and other human needs, but it also embraces business activities for economic gains (Bareja, 2014). Thus, a government can purposefully decide to focus its national agricultural activities using appropriate policy direction to determine how much impact agriculture would have on its economy. That is because agricultural activities produce food and other human needs for the benefits of man. Agriculture also provides the raw materials for further production by the industries. Thus, savings are created by both the industries and their employees as well as dependants. Such accumulated savings are subsequently re-invested with the attendant increase in the demand for labour employment for a further round of production leading to a vicious circle of economic activities that ultimately lead to economic prosperity of a country (Rostow, 1960). It can also directly determine the state of health of the productive population whether healthy or sickly - either of which has implications for national productivity level.

\section{Agriculture-Economic Growth Nexus}

The worldwide discussion of the theory of economic growth through agricultural activities was triggered off by Walt Whitman Rostow (1960) when he developed a model of the stages of economic growth arguing that economic take-off of a country must initially be led by a few individual sectors particularly the agricultural sector. His model argues that a country only needs to concentrate on one or two sectors of the economy to attain an economic take-off rather than all the sectors at the same time as pushed by the Marxists. Rostow's model is today treated as one of the most structuralised models of economic growth. By the model, Rostow argues that economies may need to depend on raw material exports from agriculture to finance the development of its industrial sector which would not by then have achieved competitiveness in the early stages of take-off. Rostow identified five economic growth stages as:

i. the traditional society 
ii. the pre-conditions to take-off

iii. take-off

iv. the drive to maturity

v. the age of high mass consumption

Rostow (1960) had argued that the traditional society is characterised by subsistence agriculture such as hunting and gathering like the early men living wholly on primary sector economy with no or limited technology. Following this stage is the "pre-conditions to take-off stage" which involves the development of more productive, commercial agriculture and cash crops beyond the needs (or consumption level) of the producers themselves alone. Part of the remainder, therefore, are largely sold or exported. The next stage of economic growth - the take-off stage - is characterised by increases in urbanisation, industrialisation proceeds, and technological breakthroughs. A major feature of this stage is that the ratio of secondary goods sector to the primary goods sector in the economy favours or shifts quickly towards secondary-goods sector i.e. talking about value-addition through manufacturing. The drive maturity stage is the next stage, characterised by diversification of the industrial base; multiple industries expand and new ones take root quickly. The last stage is the age of mass consumption expectedly characterised by the industrial-based economy with the primary sector greatly reduced in both number and importance to both the economy and society with widespread and normative consumption. Rostow's model has been criticised along the following deficient areas:

1. That the differences between stages are not properly identifiable as the conditions of the take-off and pre-take-off stage are very similar and also overlap;

2. That the model is based on American and European history and defines the American norm of high mass consumption as integral to the economic development process of all industrialized societies;

3. That the model does not apply to the Asian and the African countries as events in these countries are not justified in any stage of his model. It also has little to say about small countries and offers little hope for them; and 4. That growth becomes automatic by the time it reaches the maturity stage. This assertion has been questioned by some researchers who argue that no growth can be automatic. That growth remains static until it is pushed;

Perhaps, what Rostow did not envisage is that linearity in growth may not occur for all countries in the manner prescribed by him. Nigeria's growth experience exposes the weaknesses of Rostow's model and draws attention to the fact that Rostow wrote for the developed countries given his Western European historical experience. Nigeria tends to be at more than one or two stages at the same time judging by the conditions set out in the model 
by Rostow himself relating to investment, consumption and social trends at each of the stages.

However, in spite of the observed limitations, this paper argues that Rostow's thesis is still potent for explaining Nigeria's economic development trajectory. The paper argues that agriculture is needed to jumpstart and accelerate Nigeria's economic growth given the overwhelming evidence from some of the advanced and emerging economies. Therefore, this paper postulates that agriculture remains the most veritable window for Nigeria to step into the next stage of economic growth and development.

\section{Review of Empirical Literature \\ Historical Evidence of Agriculture-Instigated Economic Growth in Developed Economies}

Agriculture has been linked to economic growth around the globe taking evidence from some of the present industrialised nations. For example, the literature reveals the contributions of agriculture to the economic growth and development of England, USA and Japan at the critical periods of their agricultural development. Literature shows that agriculture did not only propel the economic growth of these industrialised countries, but it also facilitated the structural transformation and diversification of their economies (Akinboyo, 2008). Agriculture enabled these countries to utilise fully their factor endowments and the needed sectoral linkages and thus reduced dependency on some of their exhaustible natural resources for sustenance. Literature is replete with how within the period 1750-1875, England experienced prosperity in agriculture which she used in developing the UK that eventually led to increased food production due to rise in prices resulting in higher capital investment and returns on investment (Johnston and Kilby, 1975). England converted her agricultural development into absorbing its huge labour force not only by the agricultural sector but also by the industrial sector which was then springing up to catch up with the improvement in the agricultural sector. Capital from agriculture in the form of land and taxes from farmers' income including taxes from the shadow and ancillary activities served the development of other sectors leaving agriculture as the net contributor of capital during the period under reference in England (Ojo, 1991).

Agriculture played a more prominent role in the strategic development of the US economy in the same way it contributed to the Japanese economy (Johnston and Kilby, 1975). During the $19^{\text {th }}$ and $20^{\text {th }}$ centuries, US opened up new lands. With vast land low population, US agricultural growth was characterised not only by high capital-labour ratios but also by high farm inputs and capital formation rates assisted by high immigration from foreign countries accompanied by foreign capital 
investments (Ojo, 1991). All these culminated in high and bumper food production and supplies with ready markets in England and other Western European countries. Agriculture became the major export and foreign exchange earner for the US economy accounting for about $83 \%$ of merchandise exports in the 1920s and $81 \%$ in the 1970s leading to twice total export values (Ojo, 1991).

For Japan, its overall economic growth and development were attributed mainly to the impressive agricultural development strategies (Nicholls, 1964 cited in Ojo, 1991) which can still be found relevant to many developing countries in contemporary times including Nigeria. Japan as at then was characterised by disjointed economic policies, particularly in agriculture, (Ojo, 1991) with fast growing population, low per-capita incomes and small fragmented farm units like most of the modern day SubSaharan African countries. Between 1881-1890 and 1911-1920, a thirty year period, Japan increased her per-capita food supplies by over $20 \%$, land area cultivated by $21 \%$ and yield-per-acre by $46 \%$; all of which led to an increase in agricultural output by $77 \%$ with labour force dropping by $14 \%$ (Johnston and Mellor, 1961). The Japanese model was underpinned by a strategic policy which centred on small-scale farming that involved all farmers in Japan.

\section{Economic Growth via Agricultural Activities: Evidence from Developing Countries}

Within the developing countries, there are several examples of countries that have transformed their agricultural sector and used the fortunes to grow and develop their economies. Chief among these countries are the Asian tigers like Malaysia, China, Vietnam, and Thailand. From the southern American countries is Brazil. In Africa, we can mention countries like Malawi, Kenya, and Ghana. The agricultural transformation in the Asian countries led to some impressive growth in their agricultural sectors spanning three decades with per capita annual growth rates of $3.5 \%, 2.6 \%$, $2.0 \%$, and $1.4 \%$ respectively (NBS, 2014). The annual growth rate per capita of Brazil over the same period was $1.8 \%$. Malawi became self-sufficient in food production within its one-year implementation of agricultural transformation. Its Maize production doubled in 2006 and tripled in 2007 (NBS, 2014) via national input support programme which targeted clusters of farmers with small holdings using the Japanese model. In the same vein, Kenya became number one in the global horticulture market creating eight million jobs for the subsector using private sector market-driven institutions. In particular, Thailand's agricultural revolution resulting from the investments predicated on its annual per-capita growth rate of $1.4 \%$ led to an annual growth rate of $4.5 \%$ in the manufacturing sector thereby drastically 
reducing the unemployment rate from $4.5 \%$ in 2000 to $1.2 \%$ in 2011 (NBS, 2014).

Of most pertinent to Nigeria is the experience of Brazil: how it became an emerging economy through the development and strategic implementation of appropriate agricultural policies and programmes. In the 1970s and 1980s, Brazil like all the other oil exporting countries including Nigeria experienced a downturn in oil prices. Brazil took advantage of the opportunity to diversify its economy into agricultural activities. Brazil discovered during the period a by-product of sugarcane called ethyl alcohol (ethanol) which when mixed with petroleum derivatives produces a brand of renewable fuel known as gasohol/alcogas or green petrol for motor vehicles (Ogen, 2011; Brown, 1997). Today, Brazil owns and operates the largest gasohol production plant in the world (Ogen, 2007). The plant in the 1980s accounted for about half of the fuel consumption of Brazilian motorists (Ogen, 2002) thus, helping to reduce Brazil's reliance on imported fuel. This has also helped Brazil to save scarce foreign exchange and consolidate the sugar industry's role in the energy sector.

In Nigeria, several writers have found a nexus between economic growth and agricultural activities majority of which are positive. Anyanwu et al. (2010), for instance, using the correlation matrix investigated the relationship between the share of some major staple food crops (agricultural activities) of Nigeria and the GDP from 1990 to 2001. They found a strong and significant positive correlation between the two except for wheat. Uma et al. (2013), using augmented Dickey-Fuller and Phillips-Perron to test for unit root and John co-integration, concluded that there was a long-run relationship between agricultural practices and gross domestic products (GDP) which was used as a proxy for economic growth. In specific terms, Uma et al. (2013)'s result showed that crop production, livestock, and fishing had a significant influence on the economic growth of Nigeria. Others whose results of the study showed positive relationships between agriculture and economic growth include but not limited to Umaru and Zubairu (2012), Agbogo and Aja (2011), Lawal (2011). Conversely, Ugwu and Kanu (2012) examined the agricultural policies in Nigeria over three decades and came to the conclusion that the overall economic reform strategies developed and operated by Nigeria over the period focused only on the achievement of food self-sufficiency and food security, generation of gainful employment, increased production of raw materials for industries, increased production and processing of export crops, rational utilization of agricultural technologies for the improvement of life of its citizens. However, they concluded that agriculture only relatively contributed minimally during the period in terms of output, market, foreign exchange and capital formation or transfer as a result of policy instability, poor coordination of policies, poor 
implementation and mismanagement of policy instruments and lack of transparency. Some writers have blamed the poor performance of agriculture in Nigeria's economic growth to poor and lip-service paid to policy implementation (Umaru and Zubairu, 2012). According to the duo, the structural changes in the economy as a result of the changes in export revenues (mainly from crude oil) are consequences of the neglect of fundamentally important sectors namely agriculture and industries.

\section{The Dynamics of Agricultural Policies in Nigeria: 1960-2014}

In an attempt to achieve economic growth, successive governments in Nigeria embarked on various policy measures aimed at improving the agricultural sector to serve as the engine of growth for other sectors (Aigbokhan, 1988). The policy initiatives by various administrations, as depicted in Appendix 1, began since independence (1960). Arguably, what could be termed well-articulated agricultural policy documents was formally launched in Nigeria in 1988 (Agbogo and Aja, 2011). Despite the long presence of such policies, they failed to establish for Nigeria a systematic focus on her agricultural planning history (Ogen, 2007; Manyong et al., 2003). These documents reveal a lack of conscious effort to purposely prioritise Nigeria's agricultural development that is based on the identified components needed for modern agriculture (Manyong et al., 2003). These documents ran short of the Brazilian model which placed emphasis on timeline (within time periods) to consciously pursue and implement one or more specific areas of commodity to produce, those to process by adding value, those to market through either internal commercialization or external trade or both, and finally institutional support services for agro-industry (Manyong, et al, 2003). Instead, what has happened in the case of Nigeria over the years is that, programmes such as Farm settlement schemes (FSS), River Basin Development Authorities (RBDAs) and Green Revolution scheme (GRS) have all been developed and adopted with the intention just to support and facilitate increased production of commodities in the country. Manyong et al. (2003) noted that some of the agricultural policies and programmes from pre-independence to early 2000 included:

i. Farm Settlement Schemes (FSS) in the early-to-mid 1950s for creating farmsteads of the Israeli Moshav type agriculture intended to increase commodity output and create employment for young school leavers; ii. River Basin Development Authorities (RBDAs) for the purpose of harnessing water resources for farmers throughout the country;

iii. Green Revolution Scheme (GRS) that encouraged all Nigerians in both urban and rural areas to go into agriculture for both commerce and provision of food for home consumption; and 
iv. Agricultural Development Programmes (ADPs) in all States of the Federation to help organize farmers into more productive agriculture through the provision of modern inputs.

Also, other policy measures and efforts made by various administrations according to Agbogo and Aja (2011) included:

i. the Food and Agricultural Organization (FAO) sponsored fertilizer supply in the early 1970 s;

ii. the National Accelerated Food Production Programme (NAFPP) in 1972;

iii. the Operation Feed the Nation Programme (OFN) in 1976;

iv. the Green Revolution Programme (GRP) in 1980;

v. the River Basin Development Authority Scheme (RBDA);

vi. $\quad$ the Integrated Agricultural Development Programme (ADP) in 1984;

vii. the Commodity Boards;

viii. the Government sponsored food production companies in the mid1980s;

ix. the Directorate of Food, Roads and Rural Infrastructures (DFRRI) in 1986 and

x. the National Agricultural Land Development Authority (NALDA) in 1992.

Interestingly, the success of each of these programmes/projects was just a temporary increase of food production only (Manyong et al., 2003). There was no deliberate and formal attempt either in all the documents or on the side of the implementers to link the sector to other sectors of the economy. No purposeful efforts were made to inbuilt components that would encourage micro, small or medium industrial clusters using the Japanese, USA and Brazilian models to cater for the processing and/or commercialization of the food outputs so as to add value. Hence, all efforts aimed at developing the economy through the agricultural sector failed woefully. However, despite these shortcomings, agriculture has played and continues to play a pivotal role in the socio-economic development of Nigeria since independence using its contribution to the GDP as a measurement index (see Table 5).

\section{Recent Growth-Based Agricultural Policy: The Agricultural Transformation Agenda}

The Agricultural Transformation Agenda of the immediate past administration (2010-2015) can be said to be the most purposeful and serious government that attempted to achieve a hunger-free Nigeria through agriculture. Its agricultural policies were intended to drive income growth, accelerate food and nutritional security, generate employment and transform Nigeria into a leading player in global food markets by making millions of 
farmers to grow wealth. The novel imprint of the administration could be anchored on facilitating access of farmers to financial services and markets, elimination of fertiliser profiteering and facilitation of the much talked-about agro-business initiatives. To achieve this vision, there was a need for a paradigm shift. The endemic structural inefficiencies involving fertiliser procurement and distribution, marketing institutions, financial value chains and agricultural investment framework were some of the old practices that were changed. The fertiliser strategy was intended to stimulate a thriving private sector fertiliser industry sequel to inefficiency in the government distribution system and wastage of resources. The subsistence farmers also were expected to be moved from their high poverty level through marketoriented/market surplus facilitated by Nigerian Incentive-based Risk Sharing for Agricultural Lending (NIRSAL) into a commercialised system that would facilitate trade and competitiveness (Federal Ministry of Agriculture and Rural Development, 2011). This was expected to be achieved through the Growth Enhancement Support (GES) investment that was targeted at 20 million farmers at an estimated cost per farmer per year of 5,000 naira.

The transformation action plan had some six targeted commodities tagged "priority agricultural commodities" for the six geopolitical zones of the country. The commodities are rice, cassava, sorghum, cocoa, cotton, maize, dairy, beef, leather, poultry, oil palm, fisheries as well as agricultural extension. Emphasis was on the value chains of each of the commodities while at the same time recognising the roles of the actors/stakeholders along the nodes of the chain, inputs requirements in achieving production targets, constraints faced and expected output. The main target was to grow the agricultural sector through the various commodities and also to generate employment opportunities. For example, rice transformation plan was intended to involve the massive local production of milled rice aimed at substituting the not-too-rich nutritional parboiled (imported) rice with the highly-nutrient-rich milled rice. The expectation was that with the advent of high quality lower cost milled rice, a significant portion of demand in the domestic rice market will shift from parboiled rice to milled rice. A projected decline in demand for high quality parboiled rice from 1.9 million metric tonnes to 1.3 million metric tonnes between 2011 and 2015, and a shift in demand for milled rice from 0 million metric tonne in 2011 to 1.1 million metric tonnes in 2015. But the conditions president to achieving all these included land, improved seeds, and fertiliser e.g. the cultivable lowland rice farm was estimated to increase from about 50,000 hectares in 2011 to 1.2 million hectares by 2014 while that of irrigated rice farm was estimated to be 300,000 hectares by 2015 . Job creation in rice production was also expected to be through primary production, plantation establishment and value chain with an estimated 1 million jobs to be created by 2015 (Federal Ministry of 
Agriculture and Rural Development, 2011). Similarly, the transformation in cassava was expected to increase the yield of cassava tuber from 12.5 metric tonnes per hectare as at 2010 to 25 metric tonnes per hectare by 2015 with 1.2 million jobs. The yield of sorghum was to increase from 0.75 metric tonnes per hectare to 2.5 metric tonnes per hectare with 150,000 jobs. 360,000 jobs were projected with increment in cocoa yield from $300 \mathrm{Kg} / \mathrm{ha}$ to $500 \mathrm{Kg} / \mathrm{ha}$ (Federal Ministry of Agriculture and Rural Development, 2011). Some of the associated facilitating policies targeted financial services, industry and market development as the old policies could not drive the present transformation strategies and therefore needed a review. So, regarding fiscal policies, there was a need to put in place zero tariffs (custom, excise and value added) for imports of agricultural and agroprocessing equipment. Expected initial impact from the transformation activities included the provision of over 3.5 million jobs within five value chains involving rice, cassava, sorghum, cocoa and cotton (Federal Ministry of Agriculture and Rural Development, 2011). Over NGN300 billion (US\$2 Billion at an exchange rate of NGN150/\$) additional income was injected into the economy through the farmers for food security by increasing production of key food staples by 20 million metric tonnes. Table 1 depicts the projected increases in outputs of the six targeted crops between 2010 when the policy was launched and 2015.

The major agricultural policy actions and achievements of the Transformation Agenda between 2010 and 2014 can be summarised as follows:

1. The decentralisation of the Ministry of Agriculture and Rural Development into the states by opening up offices and directorates thereby expanding the administrative offices to all 36 States creating 6 Regional Directorates of Agriculture for greater effectiveness;

2. The adoption of the Agricultural Policy Reform that curbed the agelong cankerworm of corruption endemic in the Federal Ministry of Agriculture in the fertiliser sales and distribution for over 40 years. Now, fertilisers are sold directly to farmers. Under the previous system, the Federal Ministry of Agriculture and Rural Development procured and distributed fertilisers to farmers. The system undermined the private sector, and only about $11 \%$ of the farmers received fertilisers. The rest were sold to friends and 'political farmers' who usually exported them;

3. The implementation of the Young Graduates Commercial Farmers Scheme in 2013 which as at 2014 absorbed about 780,000 graduates in its first phase and provided an estimated 4 million jobs in the agricultural sector in the first year. Today, Nigeria has reached an unprecedented $60 \%$ sufficiency in rice production, a feat, which the Food and Agricultural Organization $(F A O, 2014)$ recently described as capable of raising world rice 
output to a record high in a subsequent year. Additionally, the Federal Ministry of Agriculture set a clear goal to make the country self-sufficient in rice production by 2015. Actually, by 2015, the NGN356 billion spent on importation of rice had been reduced to less about NGN75 billion annually;

4. The restructuring and recapitalisation of the Nigeria Agricultural Bank to provide loans to peasant farmers at single digit interest rates. The implementation of this singular policy stood out as the most remarkable funds injection initiative ever undertaken by any government to empower rural peasant farmers and create wealth for rural dwellers;

5. The launching of the Growth Enhancement Scheme to cater for farmers who were expected to receive $50 \%$ subsidy on fertilisers, for a maximum of two bags, through the use of their mobile phones or what is popularly called the Electronic-wallet system (or E-wallet). In 120 days, over 1.2 million farmers bought their subsidised fertilisers using the E-wallet system. Over 1.5 million farmers will be reached by the end of the dry season. A total of 138,802.7 metric tonnes of fertiliser and 10,974.78 metric tonnes of seeds in 517 active redemption centres out of all the 804 centres spread across all states of the federation. The E-wallet system is the first of its kind in Africa, and already several African countries have indicated they want to implement the Nigerian system;

6. The substitution of $20 \%$ of wheat bread flour with cassava flour injected over 60 Billion Naira (US\$ 380 million) into the economy. In total, the agricultural transformation agenda added over 20 million metric tonnes of agricultural outputs to domestic food supply by 2015, including rice (2 million metric tonnes), cassava (17 million metric tonnes) and Sorghum (1 million metric tonnes). As a result of the purposeful agricultural strategy, Nigeria is today known as the world's largest producer and exporter of cassava;

7. The setting up of 14 new rice mills in 2012 with installed processing capacity of 240 metric tons of rice by the private sector while securing a US $\$ 1.2$ billion loan to install 100 large scale rice processing mills to produce 2.1 million metric tons of rice. This and other initiatives of government in 2012 alone resulted in the creation of about two million new jobs (both direct and indirect) among rural dwellers;

8. The export of dried cassava chips began in July 2012 and represented the first time that Nigeria will achieve such a commercial scale export of dried chips with the potential to earn the country US\$136 million annually. Within the same time, efforts were made to resuscitate the production of Cotton particularly in the Northeast and Northwest zones of Nigeria through the provision of improved cotton seedlings, which have been given free of charge to farmers. However, the delay in actualising this was caused by Boko Haram sect who is presently waging religious war on the country from 
the zones. The initial intention was to help in resuscitating the upstream and downstream cotton/textile subsector before the end of 2013;

9. Earmarking of over 300 Billion Naira (US\$2 billion) of additional income into the hands of the Nigerian farmers".

\section{Study Method and Discussions}

This study adopted a qualitatively logical technique to illustrate the agricultural policy directions of various administrations in Nigeria. Thus, the analysis is on the impacts of the changes of these various agricultural policy directions of successive governments on the agricultural outputs and their contributions or otherwise to the growth of the Nigerian economy in a qualitative manner using, however, numerical data evidence of various years provided by both the Central Bank of Nigeria (CBN) and National Bureau of Statistics (NBS). Figures are presented in both absolute and relative quantities as well as in percentages in tables (see appendix).

\section{A Trend Analysis of the Contributions of Agriculture to the Growth of the Nigerian Economy Percentage Share of Agriculture in Employment and Exports}

The contributions of the agricultural sector to the growth of the Nigerian economy over the review period have been summarise in tables 2-5 (see appendix). Table $2 \mathrm{a}$ indicates that agriculture employed more than 640,000 workers between 1999 and 2005 despite the consistent fall in the government expenditure allocation to the sector (see Table 3) and its declining importance in the economy due to government neglect. In absolute terms, it was the $8^{\text {th }}$ largest employer of labour in the economy over the period. Its relative importance in labour employment is reflected in its annual growth rate between 2001 and 2005 which averaged $12.47 \%$ (Table 2c). The cumulative index of employment between 1999 and 2005 was 96.3 (Table $2 b)$. In general, the sector employed a huge percentage of the labour force, especially in the 1960s-80s at which time it received a better attention of government. Although the employment rate declined consistently with the passage of time, it can be gleaned from the table that the sector employed more than $50 \%$ of the labour force throughout the period. The declining trend can be said to be consistent with expected tradition that as economic development progresses, there is naturally a gradual reallocation of the labour force from agriculture to non-agricultural sectors particularly manufacturing industry (Aigbokhan, 1988). The Commerce sector was second to the agricultural sector in the labour force. The employment capacity of the Commerce sector rose during the period from $13.0 \%$ in 1952 to 20.2 in 1985 (Table $2 \mathrm{~d}$ ). 
Agriculture also contributed to Nigeria's total exports during the review period although minimally. Table 3 shows that in 2009, 2012 and 0213, agriculture contributed more than $5 \%$ of the total exports from Nigeria to different parts of the world. Between 2010 and 2015, during the transformation agenda of the immediate past administration, agriculture made its greatest impact on the Nigerian economy when judged against the period 1996 and 2015 contributing an average of 3.63\%. Taking a longer perspective covering between 2007 and 2015 (Seven-point agenda and Transformation agenda era), Nigeria tended to revive the ailing agricultural sector which was almost totally abandoned between pre-1997 and 2006 (see allocation to the sector during the period in Table 4). In summary, although agriculture contributed modestly to the total exports of the country, it was nonetheless a major contributor to the growth of the Nigerian economy given its neglect and abandonment.

\section{Percentage Share of Agriculture in Real GDP}

Table 5 shows both the absolute and percentage share of the agricultural sector to GDP over the review period. The table shows that per yearly share of agriculture in real GDP was greater than $50 \%$ for a period of eight years (1960 and 1968) indicating that agriculture contributed more than half of Nigeria's economic growth between 1960 and 1968. The cumulative share of the agricultural sector to Nigeria's economic growth over the first four years after independence was $65.5 \%$. Immediately after the civil war, government shifted its attention to the oil sector following improvement in oil prices on the global oil market and a fall in world commodities market. Consequent upon long abandonment and neglect (Enoma, 2001; Uniamikogbo and Ewanehi, 1998), the contribution of agriculture to the total GDP plummeted as depicted in table 5. Despite that, agriculture continued to provide more than $50 \%$ of the growth in Nigeria's GDP yielding an average of $54.4 \%$ percentage share for the next five years. From 1969 up until 1980, there was a consistent decline in the share of agriculture in GDP. Indeed, given a strong agricultural policy and will of implementation, Nigeria did not borrow to prosecute the civil war which it fought between 1967 and 1970. The average contribution of the agricultural sector to the GDP during the war period averaged approximately 50\% (49.63\%). There were, however, marginal increases between 1998 and 1999 from $40.4 \%$ to $41.0 \%$ and between 2004 and 2007. A holistic review of Table 5 shows that agriculture contributed approximately $40 \%$ (39.38\%) of the overall growth of the Nigerian economy. 


\section{Foreign Private Investment (FPI) as Proxy for Market-Based Policies}

Table 6 shows the proportion of foreign private/direct investment in agriculture in the total inflows of foreign private investment in Nigeria over the fifty-four years of review averaging $0.3 \%$. It is an indication that the cummulative effects of the policy measures by successive administrations in Nigeria toward agricultural development over the period has not been strategic enough. All such policies did not win the interest of foreign investors especially regarding value addition through agro-business and cottage industry involving the private sector. Except for 1976-1984 where the share of agriculture was consistently above $2 \%$, it recorded at best $1 \%$ for all other years. From 1976 to 1984 inclusive, the cumulative average share of foreign investment in agriculture in total foreign investment to Nigeria was a meagre 3\%. Beginning from 1995 to 2008, foreign investment in agriculture was less than $1 \%$ of the total foreign investment in Nigeria. Although there was a consistent decline in FPI in agriculture in relative terms for the remainder of the period, a small improvement was noticed during the period 2011-2014 when the absolute size of FPI rose from NGN4.3 billion in 2010 to NGN21.3 billion in 2011; NGN76,725.9 in 2012; NGN82,370.2 in 2013 and a decline to NGN24,322.00 in 2014. The increase is attributable to the well thought-out Transformation agenda policy on agriculture which focused on market-based and value-added agricultural programmes.

\section{Conclusion and Recommendations}

This paper investigated the impact of agricultural sector on the economic growth of Nigeria. We established that the pivotal role played by agriculture in the industrialised economies like the USA, England and Japan can also be replicated here in Nigeria despite the present hiccup being experienced. Reference was also made to some of the developing economies like China and Brazil whose economic growth and development can be linked to agriculture. It was submitted that more than $50 \%$ of the economic growth of Nigeria within the first twelve years as an independent nation can be linked to agriculture. Therefore, if Nigeria is to return to the economic growth path, it must develop and faithfully implement an efficient agricultural policy with an inbuilt strategy for value addition using clusters of micro, small and medium agro-industries through private participation. It has been established in the literature that agriculture has the capacity and potentiality to catapult any country into a remarkable economic advancement (Rostow, 1960). It is established that agricultural policies that emphasise increase in food production only without recourse to preservation, technology, and value addition cannot endure. It was also found that due to the non-existence of a reliable agro-business model, foreign private investment in the agricultural sector has remained almost non-existent since 
the 1960s. The myriad of policy initiatives of successive administrations in agriculture beginning from 1960 till date has yielded little or no appreciable benefits regarding a well articulated agricultural road-map such as that of Brazil. The result, therefore, underscores the need to redirect attention to a tactically and strategic agricultural model that will ensure the linkage between agriculture and the other sectors of the economy (backward and forward linkages). Such a policy will ensure that Nigeria attains a sustainable economic development and food security by the year 2020 as envisaged in the Vision 20:2020 document.

Finally, our analysis acknowledges that agriculture deserves a better attention and budgetary prominence given that it helps to develop and provide the foundation for economic development. It is even more so given that a strong and efficient agricultural sector would not only enable Nigeria to diversify her mono-economy but also feed her ever increasing population, generate employment, earn higher foreign exchange and provide raw materials for agro-allied industries and market for industrial products than it is presently doing. The paper argues that given the energing backward linkage between agriculture and the other sectors of the economy particularly with the manufacturing sector (e.g. cassava for bread), the present administration must continue with the tenets of the Transformation agenda so as to sustain the gains already achieved. Hence, we recommend the following:

1. The government should increase its annual spending on the agricultural sector from the present low level so as to increase its positive impact on the economy as identified in the study. Such allocation should be more consistent so as to aid planning by agro-business owners and farmers alike. However, government must also ensure that whatever is allocated to the sector is fully and transparently utilised and not be allowed to be filtered away into the private pockets of government officials and jobbers;

2. It is true that the transformation agenda identified and resolved the problems of scarcity-cum-high cost of improved farm inputs. It also provided and improved rural infrastructure to attract investment and financial services. However, there are still issues of inefficient marketing models characterised by high marketing markups, lack of standardised grading of agricultural produce and products which require immediate government attention;

3. The present administration must not only maintain but should also fast-track the full implementation of existing policies intended to encourage agro-business activities within the value chain of the agricultural sector. Such will improve the capacity of the country in exports of value-added agricultural products rather than the present practice of exporting raw/crude agricultural produce like cocoa beans, rubber, timber $(\operatorname{logs})$, etc. It will not only encourage inflows of private capital into the agricultural sector but will 
also improve the country's foreign exchange earning capacity and balance of trade.

4. The present administration is encourgaed to not only develop and enact implementable land-tenure ownership and control rights laws but it must also have the political will to enforce them as this has over the years served as a disincentive to both foreign and local private investments in agriculture.

5. Since the transformation agenda has taken a major initiative to improve credit delivery to the Nigerian farmers and rural dwellers, the present administration should go a step further to expand the mandate of the restructured Nigerian Agricultural Cooperative and Rural Development Bank to include savings mobilisation so as to making it more relevant to the rural farmers;

6. Policy makers must factor in some of the identified issues arising from this study into agricultural policies so as to re-engineer existing policies and programmes for higher effectiveness. Such existing policies include tax holiday and tax rebates for agricultural implements and products and the proposed low interest rates to farmers on bank loans.

\section{References:}

1. Abellanosa, A.L. and Pava, H.M. (1987), Introduction to Crop Science, Central Mindanao University, Musuan, Bukidnon Publishers.

2. Agbogo, E.A and Aja, O. (2011), Analysis of the Agricultural Policies in the development of the Nigerian Economy (1960 - 2010), Journal of Agriculture, Forestry and the Social Sciences (JOAFSS), 9(1), pp. 1-13.

3. Aigbokhan, B.E. (1988), Planning, Employment and Income Distribution in Nigeria, Kristal Publications Ltd, Lagos

4. Akinboyo, O. L. (2008), Five Decades of Agricultural Policies in Nigeria: What Roles Have Statistics Played? Central Bank of Nigeria Bullion, 32(4), pp. 35-44.

5. Akinyoade, A.; Dietz, T.; Foeken, D. and Klaver, W. (2013), Agricultural Dynamics and Food Security Trends in Nigeria, A Research Report for Developmental Regimes in Africa (DRA) Project, ASC-AFCA Collaborative Research Group: Agro-Food Clusters in Africa (AFCA).

6. Alkali, R.A. (1997), The World Bank and Nigeria: Cornucopia or Pandora Box? Kaduna: Baraka Press, pp15-16.

7. Andohol, J. (2012), Nigeria's Food Security Programs: Implications for MDG's Goal of Extreme Hunger Eradication, International Journal of Business and Social Science, 3(9), pp. 243-253. 
8. Anyanwu, S.O., Ibekwe, U.C. and Adesope, O. (2010), Agriculture Share of the Gross Domestic Product and its Implication for Rural Development, International Research Journal of Applied Basic Sciences, 4(3), pp. 548-555.

9. Enoma AI, (2001), Long-Run Agricultural Growth in Nigeria: An Empirical Analysis, Journal of Policy Issues, 3(7), pp. 12-20.

10. FAO (2002), The State of Food Insecurity in the World 2002

11. Federal Ministry of Agriculture and Rural Development (2011), Agricultural Transformation Agenda: We Will Grow Nigeria's Agricultural Sector, Abuja.

12. Igudia, P.O. (2010), Global Food Crisis and Food Insecurity in Nigeria, Confluence Journal of Environmental Studies, 5, pp 80-97.

13. Johnston, B.F. and Kilby, P. (1975), Agriculture ad Structure Transformation, New York, Oxford University Press.

14. Johnston, B.F. and Kilby, P. (1975), Agriculture and Structural Transformation, Oxford University Press, New York.

15. Johnston, B.F. and Mellor, J.W. (1961), The Role of Agriculture in Economic Development, American Economic Review, 11(4).

16. Lawal, A.A. (1997), The Economy and the State from the Precolonial Times to the Present in A. Osuntokun and A. Olukoju, (eds.), Nigerian Peoples and Cultures, Ibadan: Davidson.

17. Lawal, W.A. (2011), An Analysis of Government Spending on Agricultural Sector and its Contribution to GDP in Nigeria, International Journal of Business and Social Science, 2(20), pp. 244250.

18. Manyong, V.M., Ikpi, A., Olayemi, J.K., Yusuf, S. A., Omonona, R. and Idachaba, F.S. (2003), Agriculture in Nigeria: Identifying Opportunities for Increased Commercialization and Investment, The Main Report Submitted to USAID/NIGERIA and International Institute of Tropical Agriculture (IITA).

19. Mellor, J.W. (1961), The Economics of Agricultural Development, Ithaca: Cornell University Press.

20. Nicholls, W.N. (1964), The Place of Agriculture in Economic Development cited in Ojo, M.O. (1991), Food Policy and Economic Development in Nigeria, Central Bank of Nigeria, Page Publishers Services Ltd. Nigeria.

21. Nwokeoma, J. (2008), Yar' Adua and the Food Crisis: The Road not Taken, Global Politician, Online Resource Accessed at www.globalpolitician.com on 02/09/2015.

22. Ogen, O. (2003), Patterns of Economic Growth and Development in Nigeria since 1960 in S.O. Arifalo and Ajayi, G. (eds.), Essays in Nigerian Contemporary History, First Academic Publishers, Lagos. 
23. Ogen, O. (2007), Agricultural Sector and Nigeria's Development: Comparative Perspectives from the Brazilian Agro-Industrial Economy, 1960-1995, Nebula, 4(1), pp. 184-194.

24. Ojo, M.O. (1991), Food Policy and Economic Development in Nigeria, Central Bank of Nigeria, Page Publishers Services Ltd. Nigeria.

25. Okuneye, P.A. (1992), The Problem of Declining Food Production in S.A. Olanrewaju and T. Folola (eds) Rural Development Problems in Nigeria, Avebury, Aldershot.

26. Olukunle, O.T. (2013), Challenges and Prospects of Agriculture in Nigeria: The Way Forward, Journal of Economics and Sustainable Development, 4(16), pp. 37-45

27. Rimando, T.J. (2004), Crop Science 1: Fundamentals of Crop Science, U.P Los Banos: University Publications Office.

28. Rostow, W.W. (1960), The Stages of Economic Growth: A NonCommunist Manifesto. Cambridge, Cambridge University Press.

29. Rubenstein, J.M. (2003) The Cultural Landscape: An Introduction to Human Geography, 7th eds. Upper Saddle River, NJ: Pearson Education Inc.

30. Shimada S. (1999), A Study of Increased Food Production in Nigeria: The effect of the Structural Adjustment Programme on the Local Level, Graduate School of Asian and African Area Studies, Kyoto University.

31. Ugwu, D.S. and Kanu, I.O. (2012), Effects of Agricultural Reforms on the Agricultural Sector in Nigeria, Journal of African Studies and Development, 4(2), pp. 51-59.

32. Uma, K.E., Eboh, F.E., and Obidike, P.C. (2013), Appraisal of the Influence of Agriculture on Economic Growth: Empirical Evidence from Nigeria, Journal of Economics and Finance (JESR), 1(1), PP. 73-79.

33. Umaru, A. and Zubairu, A.A. (2012), An Empirical Analysis of the Contribution of Agriculture and Petroleum Sector to the Growth and Development of the Nigerian Economy from 1960-2010, International Journal of Social Science and Education, 2(4), pp. 758-769.

34. Umoh, G.S. (2008), Governance, Policies and the growth of Nigeria's Agriculture, The Nigerian Journal of Economics and Social Sciences, 32(4), pp. 341-363.

35. Uniamikogbo, S. O. and Ewanehi, S. E. (1998), Agricultural Sector's Performance in a Deregulated Economy: The Case of Nigeria, The Nigerian Journal of Economic and Management Studies, 3(2), pp. 18. 


\section{Appendix:}

Table 1: Key Performance Indicators of the Agriculture Transformation Agenda

\begin{tabular}{|cccc|}
\hline $\begin{array}{c}\text { Priority Crops } \\
\text { and Fertilizer }\end{array}$ & Indicators & As at 2010 & By 2015 \\
Rice & Paddy & 3.4 million MT & 7.4 million MT \\
& High quality processed rice & Negligible & 2.5 million MT \\
& Jobs & & 1 million \\
Cassava & Cassava Tubers & 34 million MT & 51 million MT \\
& Yield & $12.5 \mathrm{MT} / \mathrm{Ha}$ & $25 \mathrm{MT} / \mathrm{Ha}$ \\
& Jobs & & 1.2 million \\
Sorghum & Sorghum Grain & 9.3 million MT & 11.3 million MT \\
& Yield & $0.75 \mathrm{MT} / \mathrm{Ha}$ & $2.5 \mathrm{MT} / \mathrm{Ha}$ \\
& Jobs & & 150,000 \\
Cocoa & Cocoa Beans & $250,000 \mathrm{MT}$ & $500,000 \mathrm{MT}$ \\
& Yield & $300 \mathrm{Kg} / \mathrm{Ha}$ & $500 \mathrm{Kg} / \mathrm{Ha}$ \\
& Jobs & & 360,000 \\
Cotton & Cotton Lint & $20,000 \mathrm{MT}$ & $140,000 \mathrm{MT}$ \\
& Yield & $150 \mathrm{Kg} / \mathrm{Ha}$ & $400 \mathrm{Kg} / \mathrm{Ha}$ \\
Fertilizer & Jobs & & 125,000 \\
& Number of Farmers Reached & 550,000 & $20,000,000$ \\
\hline
\end{tabular}

Adapted from NBS (2014): Special Documentary

Table 2a: Total Employment in Industries and Businesses

\begin{tabular}{|ccccccccc} 
& \multicolumn{7}{c}{ TOTAL EMPLOYMENT } \\
ECONOMIC & 1999 & 2000 & 2001 & 2002 & 2003 & 2004 & 2005 & Total \\
ACTIVITY & & & & & & & & \\
Agriculture & 76,54 & 79,92 & 80,70 & 81,25 & 88,38 & 109,5 & 123,7 & 640,08 \\
Manufacturing & 1,916, & 1,835, & 1,905, & 1,849, & 1,944, & 1,987, & 1,912, & 13,350, \\
Building \& & 290,5 & 307,8 & $4 \overline{76,4}$ & 409,9 & $39,7,7$ & $4 \overline{31,7}$ & 459,0 & $2,774,4$ \\
Hotels, & 537,0 & 509,6 & 572,0 & 556,2 & 544,2 & 538,2 & 520,5 & $3,778,0$ \\
Transport & 154,6 & 158,1 & 179,1 & 192,8 & 203,2 & 189,1 & 241,3 & $1,318,6$ \\
Communications & 17,40 & 28,34 & 193,6 & 198,8 & 315,0 & 325,0 & 467,2 & $1,545,6$ \\
Education & 8,228 & 8,857 & 12,44 & 18,40 & 20,39 & 21,88 & 25,78 & 115,99 \\
Minning \& & 56,13 & 18,73 & 18,73 & 19,93 & 31,94 & 33,69 & 35,86 & 215,05 \\
Utilities & 14,89 & 14,51 & 14,56 & 14,84 & 15,17 & 15,44 & 14,89 & 104,32 \\
Banking & 28,26 & 17,11 & 24,27 & 24,89 & 24,45 & 25,31 & 29,88 & 174,19 \\
Distributive & 146,5 & 145,5 & 162,4 & 177,0 & 183,5 & 190,9 & 196,5 & $1,202,6$ \\
Private & 7,047 & 8,449 & 7,639 & 7,797 & 8,804 & 9,594 & 10,20 & 59,536 \\
Real Estate \& & 75,00 & 77,81 & 85,55 & 92,98 & 94,20 & 93,99 & 103,3 & 622,89 \\
Health & 305,8 & 301,6 & 318,3 & 346,0 & 347,3 & 355,7 & 330,0 & $2,305,0$ \\
Finance & 24,10 & 28,16 & 28,18 & 28,74 & 25,35 & $2 \overline{6}, \overline{8} 4$ & 52,39 & 213,80 \\
\hline
\end{tabular}

Source: Compiled from the archives of National Bureau of Statistics for various years 
Table 2b: Index of Employment by Economic Activity

Compiled from the archives of National Bureau of Statistics for various years

\begin{tabular}{|cccccccc|}
\hline ECONOMIC ACTIVITY & 1999 & 2000 & 2001 & 2002 & 2003 & 2004 & 2005 \\
\hline Agriculture & 100 & 104.42 & 105.44 & 106.16 & 115.48 & 143.08 & 161.70 \\
Manufacturing \& & 100 & 95.74 & 99.39 & 96.47 & 101.42 & 103.69 & 99.80 \\
Building \& Construction & 100 & 105.96 & 163.97 & 141.08 & 137.24 & 148.58 & 157.97 \\
Hotels, Restaurants \& & 100 & 94.90 & 106.51 & 103.57 & 101.35 & 100.21 & 96.93 \\
Transport & 100 & 102.25 & 115.83 & 124.68 & 131.40 & 122.27 & 156.02 \\
Communications & 100 & 162.80 & 1112.56 & 1142.51 & 1809.66 & 1867.15 & 2684.06 \\
Education Services & 100 & 107.65 & 151.25 & 223.67 & 247.86 & 266.01 & 313.35 \\
Mining \& Quarrying & 100 & 33.38 & 33.38 & 35.51 & 56.90 & 60.03 & 63.89 \\
Utilities & 100 & 97.41 & 97.78 & 99.63 & 101.85 & 103.70 & 100.00 \\
Banking & 100 & 60.54 & 85.89 & 88.09 & 86.52 & 89.56 & 105.73 \\
Distributive Trade & 100 & 99.27 & 110.85 & 120.82 & 125.22 & 130.27 & 134.07 \\
Private Professional & 100 & 119.89 & 108.40 & 110.64 & 124.93 & 136.13 & 144.82 \\
Real estate \& Business & 100 & 103.74 & 114.06 & 123.97 & 125.60 & 125.32 & 137.79 \\
Health & 100 & 98.61 & 104.08 & 113.14 & 113.54 & 116.30 & 107.90 \\
Finance & 100 & 116.82 & 116.93 & 119.24 & 105.15 & 111.36 & 217.35 \\
Total & 100 & 96.74 & 111.48 & 109.84 & 116.01 & 119.00 & 123.63 \\
\hline
\end{tabular}

Table 2c: Real Growth Rate of Employment in Industries and Businesses at Constant 1999 Level, 2001-2005

\begin{tabular}{cccccc} 
Economic Activity & 2001 & 2002 & 2003 & 2004 & 2005 \\
Agriculture & 0.97 & 0.68 & 8.78 & 23.9 & 13.01 \\
Manufacturing \&Processing & 3.81 & -2.93 & 5.13 & 2.24 & -3.75 \\
Building \& Construction & 54.75 & -13.96 & -2.72 & 8.26 & 6.32 \\
Hotel, Restaurant \& Tourism & 12.24 & -2.77 & -2.14 & -1.12 & -3.28 \\
Transport & 13.28 & 7.64 & 5.39 & -6.95 & 27.6 \\
Communications & 583.38 & 2.69 & 58.39 & 3.18 & 43.75 \\
Education Services & 40.5 & 47.88 & 10.82 & 7.32 & 17.79 \\
Mining \& Quarrying & - & 6.39 & 60.23 & 5.5 & 6.44 \\
Utilities & 0.38 & 1.89 & 2.23 & 1.82 & -3.57 \\
Banking & 41.86 & 2.56 & -1.78 & 3.51 & 18.06 \\
Distributive Trade & 11.67 & 9 & 3.64 & 4.03 & 2.91 \\
Private Professional Services & -9.58 & 2.07 & 12.91 & 8.97 & 6.38 \\
Real Estate \& Business Services & 9.95 & 8.69 & 1.31 & -0.22 & 9.95 \\
Health & 5.55 & 8.71 & 0.35 & 2.43 & -7.22 \\
Finance & 0.09 & 1.98 & -11.82 & 5.9 & 95.18 \\
Total & 15.24 & -1.48 & 5.62 & 2.58 & 3.88 \\
\hline
\end{tabular}

Source: Compiled from the archives of National Bureau of Statistics for various years 
Table 2d: Distribution of Gainful Employment by Sector (\%)

\begin{tabular}{ccccccccc}
$\begin{array}{c}\text { Sectors / } \\
\text { Year }\end{array}$ & $\begin{array}{c}\text { Agric. } \\
\text { Sector }\end{array}$ & $\begin{array}{c}\text { Mining } \\
\text { and } \\
\text { Quar. }\end{array}$ & $\begin{array}{c}\text { Manuf. } \\
\text { and } \\
\text { Craft }\end{array}$ & Const. & Comm. & $\begin{array}{c}\text { Transport } \\
\text { and } \\
\text { Comm. }\end{array}$ & Services & Others \\
1952 & 78.0 & n/a & 3.0 & n/a & 13.0 & n/a & 2.0 & 4.0 \\
1970 & 69.0 & 0.2 & 12.2 & 0.6 & 12.6 & 0.7 & 3.9 & - \\
1975 & 64.0 & 0.4 & 16.8 & 0.9 & 12.2 & 0.6 & 5.0 & 0.1 \\
1980 & 60.0 & 0.4 & 17.0 & 1.1 & 15.2 & 0.6 & 0.6 & 0.2 \\
1985 & 55.3 & 0.1 & 15.9 & 2.1 & 20.2 & 3.8 & 2.0 & 0.6 \\
2003 & 59.5 & 0.4 & 1.8 & 0.6 & 0.2 & 0.8 & n/a & 6.2 \\
2004 & 59.3 & 0.1 & 1.7 & 0.6 & 0.2 & 0.9 & a/a & 6.1 \\
2005 & 58.6 & 0.1 & 1.8 & 0.6 & 0.2 & 0.8 & n/a & 6.1 \\
2006 & 58.6 & 0.1 & 1.8 & 0.6 & 0.2 & 0.8 & n/a & 6.1 \\
2007 & 58.6 & 0.1 & 1.8 & 0.6 & 0.2 & 0.8 & n/a & 6.1 \\
\hline
\end{tabular}

Source: Adapted from Aigbokhan (1988) and Annual Abstract of Statistics, 2008

Table 3: Agriculture Exports Vis-à-vis Total Exports: 1996- 2015 (NGN 'Million)

\begin{tabular}{|cccc|}
\hline $\begin{array}{c}\text { Sectors / } \\
\text { Year }\end{array}$ & $\begin{array}{c}\text { Total } \\
\text { Exports }\end{array}$ & Agricultural Sector & \% Contribution \\
\hline 1996 & $741,752.0$ & $14,853.1$ & 2.00 \\
1997 & $785,472.7$ & $1,279.7$ & 0.16 \\
1998 & $483,193.6$ & $2,064.4$ & 0.43 \\
1999 & $1,559,299.5$ & $4,855.2$ & 0.31 \\
2000 & $2,745,102.2$ & $3,913.2$ & 0.14 \\
2001 & $2,007,127.0$ & 392.7 & 0.02 \\
2002 & $2,167,412.5$ & $20,484.6$ & 0.95 \\
2003 & $3,109,288.4$ & 948.9 & 0.03 \\
2004 & $5,129,025.6$ & $1,460.7$ & 0.03 \\
2005 & $6,621,303.7$ & $4,349.5$ & 0.07 \\
2006 & $7,555,141.48$ & $28,304.82$ & 0.37 \\
2007 & $6,881,501.65$ & $121,311.59$ & 1.76 \\
2008 & $9,568,949.24$ & $132,967.33$ & 1.39 \\
2009 & $7,434,543.81$ & $376,009.29$ & 5.06 \\
2010 & $13,009,905.73$ & $476,693.57$ & 3.66 \\
2011 & $19,035,952.20$ & $469,369.80$ & 2.47 \\
2012 & $22,446,320.20$ & $1,219,969.9$ & 5.44 \\
2013 & $14,245,271.60$ & $756,434.30$ & 5.31 \\
2014 & $17,203,878.50$ & $314,925.40$ & 1.83 \\
2015 & $3,230,159.60$ & $99,487.40$ & 3.08 \\
\hline
\end{tabular}

Compiled from the archives of National Bureau of Statistics for various years 
Table 4: A Snap-Shots of Federal Government Budgetary Allocation to Agriculture

\begin{tabular}{|c|c|c|c|}
\hline Year & $\begin{array}{c}\text { Federal Government Total } \\
\text { Expenditure } \\
\text { (NGN'Million) } \\
\end{array}$ & $\begin{array}{l}\text { Capital Exp. In } \\
\text { Agriculture } \\
\text { (NGN' Million) } \\
\end{array}$ & $\begin{array}{c}\text { Share of Total } \\
(\%)\end{array}$ \\
\hline 1962 & 178.4 & 35.0 & 19.6 \\
\hline 1966 & 295.2 & 35.0 & 11.6 \\
\hline 1970 & 838.8 & 41.0 & 4.9 \\
\hline 1975 & $4,902.7$ & 329.7 & 6.7 \\
\hline 1977 & $7,251.3$ & 400.8 & 5.5 \\
\hline 1979 & $7,406.7$ & 457.0 & 6.2 \\
\hline 1980 & $14,113.9$ & 469 & 3.3 \\
\hline 1981 & $11,438.4$ & 809 & 7.1 \\
\hline 1982 & $12,940.4$ & 1,069 & 8.3 \\
\hline 1983 & $9,690.1$ & 1,214 & 12.5 \\
\hline 1984 & $9,553.3$ & 286 & 3.0 \\
\hline 1985 & $14,828.8$ & 346.9 & 2.3 \\
\hline 1986 & $16,773.7$ & 412.4 & 2.5 \\
\hline 1987 & $22,018.7$ & 515.3 & 2.3 \\
\hline 1988 & $27,749.6$ & 742.9 & 2.7 \\
\hline 1989 & $41,028.3$ & $1,885.0$ & 4.6 \\
\hline 1990 & $61,149.1$ & $1,856.2$ & 3.0 \\
\hline 1991 & $66,584.4$ & $1,427.7$ & 2.1 \\
\hline 1992 & $92,890.2$ & $1,406.2$ & 1.5 \\
\hline 1993 & $233,846.5$ & $2,908.1$ & 1.2 \\
\hline 1994 & $210,437.5$ & $3,362.1$ & 1.6 \\
\hline 1995 & $256,520.8$ & $3,924.6$ & 1.5 \\
\hline 1996 & $337,217.6$ & $3,892.8$ & 1.2 \\
\hline 1997 & $428,215.2$ & $6,247.4$ & 1.5 \\
\hline 1998 & $487,113.4$ & $8,876.6$ & 1.8 \\
\hline 1999 & $947,690.0$ & $6,912.6$ & 0.7 \\
\hline 2000 & $701,000.1$ & $5,761.7$ & 0.8 \\
\hline 2001 & $1,017,996.5$ & $57,879.0$ & 5.7 \\
\hline 2002 & $1,020,178.1$ & $32,364.4$ & 3.2 \\
\hline 2003 & $1,225,988.3$ & $8,510.9$ & 0.7 \\
\hline 2004 & $1,384,000.0$ & $38,669.8$ & 2.8 \\
\hline 2005 & $1,743,200.0$ & $56,734.0$ & 5.8 \\
\hline 2006 & $1,842,587.7$ & $65,843.7$ & 6.6 \\
\hline 2007 & $2,348,593.0$ & $63,942.1$ & 6.4 \\
\hline $2008^{1}$ & $3,240.8$ & 106.4 & 3.3 \\
\hline $2009^{1}$ & $3,456.9$ & 138.3 & 4.0 \\
\hline $2010^{1}$ & $4,194.6$ & 28.2 & 6.7 \\
\hline $2011^{1}$ & $4,712.1$ & 41.2 & 8.7 \\
\hline $2012^{1}$ & $4,605.4$ & 33.3 & 7.2 \\
\hline $2013^{1}$ & $5,185.3$ & 39.4 & 7.6 \\
\hline Total & 998 & 908 & 90 \\
\hline
\end{tabular}

Source: CBN Statistical Bulleting and Annual Reports for various years Note: $/^{1}$ in billion naira 
Table 5: The Contribution of Agriculture to the Real Gross Domestic Product (GDP) of Nigeria from 1960-2013 (NGN' Million)

\begin{tabular}{|c|c|c|c|}
\hline Year & $\begin{array}{c}\text { Total Real } \\
\text { GDP (NGN' Million) }\end{array}$ & $\begin{array}{c}\text { Contribution of } \\
\text { Agriculture to GDP (NGN' } \\
\text { Million) }\end{array}$ & $\begin{array}{l}\text { Share of Agriculture in GDP } \\
(\%)\end{array}$ \\
\hline 1960 & $2,489.0$ & $1,599.8$ & 64.3 \\
\hline 1961 & $2,501.2$ & $1,553.8$ & 62.1 \\
\hline 1962 & $2,597.6$ & $1,605.8$ & 61.8 \\
\hline 1963 & $2,825.6$ & $1,737.8$ & 61.5 \\
\hline 1964 & $2,947.6$ & $1,731.4$ & 58.7 \\
\hline 1965 & $3,146.8$ & $1,742.2$ & 55.3 \\
\hline 1966 & $3,044.8$ & $1,581.8$ & 51.9 \\
\hline 1967 & $2,527.3$ & $1,358.0$ & 53.7 \\
\hline 1968 & $2,543.8$ & $1,338.0$ & 52.6 \\
\hline 1969 & $3,225.5$ & $1,530.5$ & 47.5 \\
\hline 1970 & $4,219.0$ & $1,887.7$ & 44.7 \\
\hline 1971 & $4,715.5$ & $1,985.2$ & 42.1 \\
\hline 1972 & $4,892.8$ & $1,861.1$ & 38.0 \\
\hline 1973 & $5,310.0$ & $1,808.7$ & 34.0 \\
\hline 1974 & $15,919.7$ & $3,658.3$ & 23.0 \\
\hline 1975 & $27,172.0$ & $7,639.4$ & 28.1 \\
\hline 1976 & $29,146.5$ & $6,838.4$ & 23.5 \\
\hline 1977 & $31,520.3$ & $7,401.6$ & 23.5 \\
\hline 1978 & $29,212.4$ & $6,713.0$ & 23.0 \\
\hline 1979 & $29,948.0$ & $6,033.5$ & 20.1 \\
\hline 1980 & $31,546.8$ & $6,501.8$ & 20.6 \\
\hline 1981 & $205,222.1$ & $57,989.7$ & 28.3 \\
\hline 1982 & $199,685.3$ & $59,450.8$ & 29.8 \\
\hline 1983 & $185,598.1$ & $59,009.6$ & 31.8 \\
\hline 1984 & $183,561.0$ & $55,918.2$ & 30.5 \\
\hline 1985 & $201,036.3$ & $65,748.4$ & 32.7 \\
\hline 1986 & $205,971.4$ & $72,135.2$ & 35.0 \\
\hline 1987 & $204,806.5$ & $69,608.1$ & 34.0 \\
\hline 1988 & $219,875.6$ & $76,753.7$ & 34.9 \\
\hline 1989 & $236,729.6$ & $80,876.0$ & 34.2 \\
\hline 1990 & $267,550.0$ & $84,344.6$ & 31.5 \\
\hline 1991 & $265,379.1$ & $87,503.5$ & 33.0 \\
\hline 1992 & $271,365.5$ & $89,345.4$ & 37.8 \\
\hline 1993 & $274,833.3$ & $90,596.5$ & 37.8 \\
\hline 1994 & $275,450.6$ & $92,833.0$ & 37.7 \\
\hline 1995 & $281,407.4$ & $96,220.7$ & 37.2 \\
\hline 1996 & $293,745.4$ & $100,216.2$ & 39.0 \\
\hline 1997 & $302,022.5$ & $104,514.0$ & 39.4 \\
\hline 1998 & $310,890.1$ & $108,814.1$ & 40.4 \\
\hline 1999 & $312,183.5$ & $114,570.7$ & 41.0 \\
\hline 2000 & $329,176.7$ & $117,945.1$ & 35.8 \\
\hline 2001 & $356,994.3$ & $122,522.3$ & 34.3 \\
\hline 2002 & $433,203.5$ & $190,133.4$ & 43.9 \\
\hline 2003 & $477,533.0$ & $203,409.9$ & 42.6 \\
\hline 2004 & $527,576.0$ & $216,208.5$ & 4I.0 \\
\hline 2005 & $561,931.4$ & $231,463.6$ & 41.2 \\
\hline 2006 & $595,821.6$ & $248,599.0$ & 41.7 \\
\hline 2007 & $634,251.1$ & $266,477.2$ & 42.0 \\
\hline 2008 & $674,889.0$ & $263,913.1$ & 39.1 \\
\hline 2009 & $718,980.0$ & $283,180.0$ & 39.4 \\
\hline 2010 & $776,330.0$ & $317,280.0$ & 40.9 \\
\hline 2011 & $834,000.0$ & $235,180.0$ & 28.2 \\
\hline 2012 & $888,890.0$ & $348,490.0$ & 39.1 \\
\hline $2013^{1}$ & $950,110.0$ & $365,280.0$ & 38.5 \\
\hline Total & $12,809,562.1$ & $5,044,638.3$ & 39.38 \\
\hline
\end{tabular}

Source: Compiled from the CBN Statistical Bulleting and Annual Reports for various years 
Table 6: Contributions of the Agricultural Sector to Total Foreign Private Investment in Nigeria from 1962-2014 (NGN' Million)

\begin{tabular}{|c|c|c|c|}
\hline Year & $\begin{array}{l}\text { Total Foreign Private } \\
\text { Investment to Nigeria } \\
\text { (NGN'Million) } \\
\end{array}$ & $\begin{array}{c}\text { Total Foreign Private Investment } \\
\text { in Agricultural Sector (NGN' } \\
\text { Million) }\end{array}$ & $\begin{array}{c}\text { Share of Agriculture in Total } \\
\text { Foreign Investment to Nigeria } \\
(\%)\end{array}$ \\
\hline 1962 & 441.8 & 8.6 & 1.9 \\
\hline 1963 & 517.2 & 9.8 & 1.9 \\
\hline 1964 & 643.6 & 10.8 & 1.7 \\
\hline 1965 & 754.0 & 11.7 & 1.6 \\
\hline 1966 & 833.6 & 9.6 & 1.1 \\
\hline 1967 & 948.0 & 11.0 & 1.2 \\
\hline 1968 & $1,021.4$ & 11.6 & 1.1 \\
\hline 1969 & 881.6 & 11.0 & 1.2 \\
\hline 1970 & $1,003.2$ & 11.2 & 1.1 \\
\hline 1971 & $1,322.8$ & 15.4 & 1.2 \\
\hline 1972 & $1,571.1$ & 9.4 & 0.6 \\
\hline 1973 & $1,763.7$ & 7.9 & 0.4 \\
\hline 1974 & $1,812.1$ & 20.7 & 1.1 \\
\hline 1975 & $2,287.5$ & 19.2 & 0.8 \\
\hline 1976 & $2,339.0$ & 21.9 & 0.9 \\
\hline 1977 & $2,531.4$ & 75.0 & 3.0 \\
\hline 1978 & $2,663.2$ & 117.6 & 4.4 \\
\hline 1979 & $3,153.1$ & 120.8 & 3.8 \\
\hline 1980 & $3,620.1$ & 120.5 & 3.3 \\
\hline 1981 & $3,757.9$ & 120.5 & 3.2 \\
\hline 1982 & $5,382.8$ & 120.5 & 2.2 \\
\hline 1983 & $5,949.5$ & 127.8 & 2.1 \\
\hline 1984 & $6,418.3$ & 128.5 & 2.0 \\
\hline 1985 & $6,804.0$ & 126.0 & 1.9 \\
\hline 1986 & $9,313.6$ & 128.2 & 1.4 \\
\hline 1987 & $9,993.6$ & 117.3 & 1.2 \\
\hline 1988 & $11,339.2$ & 128.9 & 1.1 \\
\hline 1989 & $10,899.6$ & 134.8 & 1.2 \\
\hline 1990 & $10,436.1$ & 334.7 & 3.2 \\
\hline 1991 & $12,243.5$ & 382.8 & 3.1 \\
\hline 1992 & $20,512.7$ & 386.4 & 1.9 \\
\hline 1993 & $66,787.0$ & $1,214.9$ & 1.8 \\
\hline 1994 & $70,714.6$ & $1,208.5$ & 1.7 \\
\hline 1995 & $119,391.6$ & $1,209.0$ & 1.0 \\
\hline 1996 & $122,600.9$ & $1,209.0$ & 1.0 \\
\hline 1997 & $128,331.8$ & $1,209.0$ & 0.9 \\
\hline 1998 & $152,409.6$ & $1,209.0$ & 0.8 \\
\hline 1999 & $154,188.6$ & $1,209.0$ & 0.8 \\
\hline 2000 & $157,535.4$ & $1,209.0$ & 0.8 \\
\hline 2001 & $162,343.4$ & $1,209.0$ & 0.7 \\
\hline 2002 & $166,631.6$ & $1,209.0$ & 0.7 \\
\hline 2003 & $178,478.0$ & $1,209.0$ & 0.7 \\
\hline 2004 & $249,220.6$ & $1,209.0$ & 0.7 \\
\hline 2005 & $324,656.7$ & $1,209.0$ & 0.37 \\
\hline 2006 & $481,239.1$ & $1,209.0$ & 0.25 \\
\hline 2007 & $552,498.6$ & $1,329.9$ & 0.31 \\
\hline 2008 & $399,841.9$ & $1,999.2$ & 0.02 \\
\hline 2009 & $441,271.3$ & $2,647.6$ & 0.02 \\
\hline 2010 & $5,995,703.6$ & $4,344.7$ & 0.07 \\
\hline 2011 & $7,903,769.7$ & $21,331.2$ & 0.27 \\
\hline 2012 & $16,615,915.0$ & $76,725.9$ & 0.42 \\
\hline 2013 & $21,318,375.3$ & $82,370.2$ & 0.39 \\
\hline 2014 & $20,750,760.6$ & $24,322.0$ & 0.12 \\
\hline
\end{tabular}

Source: compiled from CBN Statistical Bulleting and Annual Reports for various years 
Table 7: Administration and Agricultural Policies/Programmes in Nigeria since

Independence (1960-2014)

\begin{tabular}{|c|c|c|c|c|c|c|c|}
\hline $\begin{array}{l}\text { S/ } \\
\text { No }\end{array}$ & Period & $\begin{array}{l}\text { Length } \\
\text { of } \\
\text { Time } \\
\end{array}$ & $\begin{array}{l}\text { Head of } \\
\text { Govt. }\end{array}$ & $\begin{array}{l}\text { Type of } \\
\text { Govt. }\end{array}$ & Policies & Date & Objective \\
\hline 1 & $\begin{array}{l}\text { Oct. } 1960 \\
\text { to Jan. } 1966\end{array}$ & 6 & $\begin{array}{l}\text { Tafawa } \\
\text { Balewa }\end{array}$ & Civilian & $\begin{array}{c}\text { Nigerian Research Institute } \\
\text { Acts }\end{array}$ & 1964 & $\begin{array}{c}\text { To promote research in } \\
\text { agricultural and other } \\
\text { areas }\end{array}$ \\
\hline 2 & $\begin{array}{l}\text { Jan. } 1966 \text { to } \\
\text { July } 1966\end{array}$ & $1 / 2$ & $\begin{array}{l}\text { Aguiyi- } \\
\text { Ironsi }\end{array}$ & Military & - & - & - \\
\hline 3 & $\begin{array}{l}\text { July } 1966 \text { to } \\
\text { July } 1975\end{array}$ & 9 & $\begin{array}{l}\text { Yakubu } \\
\text { Gowon }\end{array}$ & Military & $\begin{array}{l}\text { (i) Agricultural Research } \\
\text { Council of Nigeria Decree } \\
\text { (ii) Agricultural Research } \\
\text { Institute Decree } \\
\text { (iii) National Accelerated Food } \\
\text { Production Project (NAFPP) } \\
\text { (iv) Integrated Agric. } \\
\text { Development Projects } \\
\text { (v) Nigerian Agric. And } \\
\text { Cooperative Bank } \\
\text { (vi) Specialized Marketing } \\
\text { Boards } \\
\text { (vii) National Grains and } \\
\text { Roots Cultivation Programme }\end{array}$ & $\begin{array}{l}1971 \\
1973 \\
1973 \\
\\
1973 \\
1973 \\
\\
1975 \\
1975\end{array}$ & $\begin{array}{c}\text { To coordinate all } \\
\text { agricultural research } \\
\text { To establish institute to } \\
\text { conduct research in any } \\
\text { field of agriculture } \\
\text { To accelerate Production } \\
\text { of major staples } \\
\text { To enhance adoption of } \\
\text { new Agric. Technology } \\
\text { by farmers } \\
\text { To make credit available } \\
\text { to farmers } \\
\text { To fix commodity prices. } \\
\text { To accelerate production } \\
\text { of grains and root crops. }\end{array}$ \\
\hline 4 & $\begin{array}{l}\text { July } 1975 \text { to } \\
\text { Feb. } 1976 \\
\end{array}$ & $1 / 2$ & $\begin{array}{c}\text { Murtala } \\
\text { Muhammed } \\
\end{array}$ & Military & - & - & 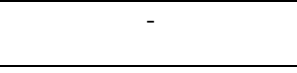 \\
\hline 5 & $\begin{array}{l}\text { Feb. } 1976 \text { to } \\
\text { Oct. } 1979\end{array}$ & 3 & $\begin{array}{l}\text { Olusegun } \\
\text { Obasanjo }\end{array}$ & Military & $\begin{array}{l}\text { Operation Feed the Nation } \\
\text { (ii) River Basin Development } \\
\text { Authorities } \\
\text { (iii) Agricultural Credit } \\
\text { Guarantee Scheme } \\
\text { (iv) Rural Banking Scheme } \\
\text { (v) Land Use Act }\end{array}$ & $\begin{array}{r}1976 \\
1977 \\
\\
1977 \\
1977 \\
1978\end{array}$ & $\begin{array}{c}\text { To mobilize the public to } \\
\text { participate in agricultural } \\
\text { production } \\
\text { To develop the country's } \\
\text { land and water resources } \\
\text { To reduce the risk borne } \\
\text { by commercial banks and } \\
\text { make credit available to } \\
\text { farmers. } \\
\text { To encourage rural } \\
\text { banking habit. } \\
\text { To make land available } \\
\text { for agricultural purposes, } \\
\text { etc. }\end{array}$ \\
\hline 6 & $\begin{array}{l}\text { Oct. } 1979 \text { to } \\
\text { Dec. } 1983 \\
\end{array}$ & 4 & $\begin{array}{l}\text { Shehu } \\
\text { Shagari } \\
\end{array}$ & Civilian & Green Revolution Programme & 1980 & $\begin{array}{c}\text { To increase agricultural } \\
\text { production }\end{array}$ \\
\hline 7 & $\begin{array}{l}\text { Dec. } 1983 \text { to } \\
\text { Aug. } 1985\end{array}$ & 1 & $\begin{array}{l}\text { Muhamadu } \\
\text { Buhari }\end{array}$ & Military & $\begin{array}{c}\text { Increase in the number of } \\
\text { River Basin Authorities from } \\
11 \text { to } 18\end{array}$ & 1984 & - \\
\hline 8 & $\begin{array}{l}\text { Aug. } 1985 \text { to } \\
\text { Aug. } 1993\end{array}$ & 8 & $\begin{array}{l}\text { Ibrahim } \\
\text { Babangida }\end{array}$ & Military & $\begin{array}{l}\text { (i) Directorate for Foods, } \\
\text { Roads, and Rural } \\
\text { Infrastructure. } \\
\text { (ii) Reorganization of the } \\
\text { River Basin Authorities } \\
\text { (iii) Abolition of the Marketing } \\
\text { Board } \\
\text { (iv) Trade Liberalization } \\
\text { Policy } \\
\text { (v) National Directorate for } \\
\text { Employment. } \\
\text { (vi) National Agric. Insurance } \\
\text { Scheme }\end{array}$ & $\begin{array}{r}1986 \\
1986 \\
1986 \\
1986 \\
1986 \\
1987 \\
1991\end{array}$ & $\begin{array}{c}\text { To promote rural } \\
\text { development. } \\
\text { To enhance the earnings } \\
\text { of farmers } \\
\text { To encourage export } \\
\text { employment } \\
\text { To reduce the risk burden } \\
\text { on farmers } \\
\text { To develop agricultural } \\
\text { land in the country }\end{array}$ \\
\hline
\end{tabular}




\begin{tabular}{|c|c|c|c|c|c|c|c|}
\hline & & & & & $\begin{array}{l}\text { (vii) National Land } \\
\text { Development Authority }\end{array}$ & & \\
\hline 9 & $\begin{array}{l}\text { Aug. } 1993 \text { to } \\
\text { Nov. } 1993\end{array}$ & $1 / 4$ & $\begin{array}{c}\text { Ernest } \\
\text { Shonekan }\end{array}$ & Civilian & $\begin{array}{l}\text { Merger of the Directorate for } \\
\text { Food, Road and Rural } \\
\text { Infrastructure (DFRRI) with } \\
\text { Federal Ministry of Water } \\
\text { Resources }\end{array}$ & 1993 & - \\
\hline 10 & $\begin{array}{l}\text { Nov. } 1993 \text { to } \\
\text { June } 1998\end{array}$ & $43 / 4$ & $\begin{array}{c}\text { Sani } \\
\text { Abacha }\end{array}$ & Military & $\begin{array}{c}\text { Continuation of Babangida } \\
\text { programmes }\end{array}$ & - & - \\
\hline 11 & $\begin{array}{c}\text { June } 1998 \text { to } \\
\text { May } 1999\end{array}$ & - & $\begin{array}{c}\text { Abdul } \\
\text { Salami } \\
\text { Abubakar }\end{array}$ & Military & - & - & - \\
\hline 12 & $\begin{array}{l}\text { May } 1999 \\
\text { to } 2007\end{array}$ & - & $\begin{array}{l}\text { Olusegun } \\
\text { Obasanjo }\end{array}$ & Civilian & $\begin{array}{l}\text { A series of the initiative of the } \\
\text { President targeted at particular } \\
\text { commodities to increase food } \\
\text { production in line with Vision } \\
\text { 2020, with a view to attracting } \\
\text { the attention of the highest } \\
\text { political authority for special } \\
\text { intervention in the commodity } \\
\text { sector. }\end{array}$ & - & - \\
\hline 13 & $\begin{array}{l}\text { May } 2007 \text { to } \\
2010\end{array}$ & $31 / 2$ & $\begin{array}{l}\text { Musa } \\
\text { Yaradua }\end{array}$ & Civilian & $\begin{array}{l}\text { In continuation of the vision } \\
202020 \text {, the agricultural policy } \\
\text { within the seven point agenda } \\
\text { focused on land Reforms, } \\
\text { Food Security, and } \\
\text { Agriculture. }\end{array}$ & & $\begin{array}{l}\text { Create the conducive } \\
\text { macro-environment to } \\
\text { stimulate greater private } \\
\text { sector investment in } \\
\text { agriculture } \\
\text { Rationalising the roles } \\
\text { of the tiers of } \\
\text { government in their } \\
\text { promotional and } \\
\text { supportive activities to } \\
\text { stimulate growth } \\
\text { Reorganising the } \\
\text { institutional framework } \\
\text { for government } \\
\text { intervention in the sector } \\
\text { to facilitate smooth and } \\
\text { integrated development } \\
\text { of agricultural potentials } \\
\text { - }\end{array}$ \\
\hline 14 & $\begin{array}{l}2010 \text { to May } \\
2015\end{array}$ & 5 & $\begin{array}{l}\text { Goodluck } \\
\text { Jonathan }\end{array}$ & Civilian & $\begin{array}{l}\text { This administration developed } \\
\text { the agricultural transformation } \\
\text { agenda focusing on major } \\
\text { policy reforms to eliminate } \\
\text { corruption in the seed and } \\
\text { fertilizer sectors, improve the } \\
\text { functioning of market } \\
\text { institutions, establish staple } \\
\text { crop processing zones which in } \\
\text { turn sets to attract private } \\
\text { sectors into areas of high } \\
\text { production as well as reduce } \\
\text { post-harvest losses, add value } \\
\text { to locally produced crops and } \\
\text { foster rural economic growth. }\end{array}$ & & $\begin{array}{l}\text { To improve Agricultural } \\
\text { rural infrastructure and } \\
\text { access of farmers to } \\
\text { financial services and } \\
\text { markets. } \\
\text { Eliminate corruption in } \\
\text { fertiliser deals } \\
\text { Create agro-business, } \\
\text { value addition and } \\
\text { private participation }\end{array}$ \\
\hline
\end{tabular}

Adapted from Ugwu and Kanu (2012): Effects of Agricultural Reforms on the Agricultural

Sector in Nigeria, Journal of African Studies and Development, 4(2), pp. 51-59. 